\title{
The Influence of Work Stress, Working Cost, Compensation and Work Discipline on Employee' Productivity
}

\author{
Suharno Pawirosumarto ${ }^{1}$, Dini Iriani ${ }^{2}$
}

\begin{abstract}
:
This study aims to identify the effect of work stress, workload, compensation and work discipline on work productivity of employees of PT., Tokio Marine Life Insurance Indonesia.

The research was conducted quantitatively by a descriptive associative method. Data collection was done by survey using questionnaire. The population of this research is employees of PT., Tokio Marine, as many as 259 employees.

The study population was used as the source of the sample, and the sample obtained amounted to 120 respondents. The sampling technique used was random sampling. Data were analyzed using multiple linear regression.

The results showed that job stress did not affect employee productivity with p-value 0,488. The work load has no effect on employee productivity with p-valus 0,726. Compensation affects employee productivity with p-value 0,000 and work discipline has no effect on employee productivity with $p$-value 0.923 .
\end{abstract}

Keywords: Stress work, workload, compensation, work discipline, productivity

\footnotetext{
${ }^{1}$ Magister Management, Universitas Mercubuana, Jakarta, Indonesia e-mail:

${ }^{2}$ Magister Management, Universitas Mercubuana, Jakarta, Indonesia e-mail:
} 


\section{Introduction}

The impact of globalization is increasingly widespread today and this requires us to be creative and work in high intensity environments and this leads to increased productivity of employees working in a company. Based on the results of research by Wicaksono (2015), productivity is the ability of an employee of managing and utilizing resources owned, to obtain output or optimal results in the implementation of tasks that have been charged to him and the achievement of work that has been determined. The increasingly diverse work scope, work intensification and flexibility demands have an ever-increasing impact on workers. Any company, large or small, will be intrigued by the importance of improving the level of work productivity.

The importance of increased productivity is due to the fact that high productivity levels will strengthen the State's economy which in turn will result in improvements in living standards in terms of employment, education, health, and others. The company is a tool or means to meet the needs of employees. However, the company is established not only to meet the needs of individuals, but also to relate to the viability of the company through productivity. Increasingly intense competition between companies today requires companies to survive whilst competing with other companies (Afia and Ranu, 2013).

The phenomenon mentioned above shows the important role of human resources today. Not only does support administrative tasks within the company but it has transformed into a strategic partner of the company. Company performance is not only determined by financial capital, machinery, or technology but also influenced by capital or intangible capital because the biggest asset in a company is its people, not just fixed capital. In order to advance and develop, the company must have a strategy that is able to manage and develop its employees into capital that can give added value and become a competitive advantage for the company.

This is also the concern of PT., Tokio Marine Life Insurance Indonesia. Launched from www.tokiomarine.com on September 27, 2017, as one of the largest general insurance companies in Indonesia, the company has been operating since 1975 and now the company has expanded its network by opening 7 (seven) other branch offices in Surabaya, Bandung, Medan, Semarang, Makassar, Pekanbaru, and Palembang and 3 (three) Representative Offices in Batam, Cikarang and Lampung. As an international-scale insurance company committed to providing the best quality products and services to its customers and providing comprehensive security and protection, it certainly requires reliable and competent human resources in fostering trust, safety, and certainty of uncertainty (risk) to its customers. With good quality human resources and also support from experienced and expert personnel in the field, the company will be able to provide the best service to its customers so that it has a strong position as one of the largest insurance companies in Indonesia. 
Effective competency management for human resources will provide competitive advantage in increasing profits for the company.

In line with the refinement of various policies in the field of human resources, there are things that need the attention of the management. Based on observations made at PT., Tokio Marine Life Insurance Indonesia, there is a phenomenon of decreasing productivity in employee work. The decrease in productivity is caused by several factors such as the high cost or the allocated cost for marketing operations, which is not matched by the consistent target achievement set by the company. This shows that the work productivity of PT., Tokio Marine Life Insurance Indonesia has decreased because its performance is far from productive work.

The phenomenon of productivity does not only occur in the marketing department but also by staff who do not comply with the work deadline. According to information from HRD, these last three months since May 2017, staff overtime hours are 67 hours, 55 hours and 81 hours respectively which are not offset by higher work capacity while during May and June 2017 the company's performance was insufficient (did not reach the target).

The achievement of target sales is inconsistent and the year 2017 experienced persistently deteriorating performance achievement. Initially the company experienced 3-5\% increase in target sales each year but the work team did not reach the target given by the company. Within a year only once did the company reach the target. If the achievement of the target in a year is reached by 6 times, then it can be said that the target setting is right. But if the target is only achieved once, then the company is providing a heavy workload on employees.

The heavy work load is visible from the employee's performance graph which tends to decrease. If the target set by the company is appropriate and proportional, then the achievement of the target shows a stable graph, not likely to increase or decrease. Employee's lack of discipline is shown by employee absenteeism. Some other employees, especially receptionists and Security sometimes are not on standby during working hours, and often not in place. Some employees experience delays when coming to work so compensation is cut off.

Another phenomenon indicates a mismatch between compensation and the employment pressure imposed on employees. From pre-survey results to 30 Tokio Marine employees located in Sudirman Jakarta, 18 out of 30 people stated that the compensation given by the company is not equivalent with the existing work pressure in the company. Most employees (60\%) have a perception that the high work stress must be adjusted with the compensation given. So that compensation can provide motivation to encourage employee productivity. Therefore, this study is interested to examine the effect of job stress, workload and compensation and work discipline on work productivity of employees of PT., Tokio Marine Life Insurance Indonesia. 


\section{Literature Review}

According to Davidson (2011) job stress is the feeling of distress experienced by employees in the face of work. Job stress is visible from symptoms, including unstable emotions, uneasy feelings, aloofness, sleeplessness, excessive smoking, can not relax, anxiety, tension, nervousness, blood pressure, increased, and digestive disorders.

\section{Work stress concept:}

Hariyono et al. (2009) suggest that stress is a condition of tension that affects the emotions, thinking processes, and the conditions of a person. Job stress is a process that can affect the psychological condition and disrupt a person in his job. So, stress can be managed or reduced actively in the activities of the organization or company. Moorhead and Griffin (2013) categorize the stress process into three parts, namely:

1) Adaptation syndrome commonly identifies three stages of the stress process. The initial stage is called a warning. Next, there is an actual resistance to the stressor, resulting in an increase in the normal resistance level. Eventually, fatigue appears and resistance decreases.

2) Distress is the unpleasant stress that accompanies negative events. Distress arises from excessive pressures, unreasonable demands on time, and bad news. This form of stress usually produces negative consequences for the individual.

3) Eustress is a pleasant stress that accompanies positive events. Stress sources are not always bad, for example: getting promoted, getting married, and making speeches as part of winning a big award.

\section{Factors that affect work stress:}

According to Mangkunegara (2013), there are several indicators of work stress like unstable emotions, feelings of calmness, aloofness, difficulty sleeping, excessive smoking, can not relax, anxious, tense, nervous, increase in blood pressure and digestive disorders. Mangkunegara (2013) confirmed that there are a number of working conditions that cause stress for employees, including workload that is felt too heavy, urgent deadlines, low quality supervision at work, unhealthy work climate, inadequate work authorities dealing responsibilities, work conflicts, value differences between employees and frustrated leaders at work (Bernanthos, 2018).

Mondy (2011) states that "workload are the tasks assigned to the workforce or the employee to be completed at any given time using the skills and potential of the workforce". Workload is several tasks/demands to be done which usually have a huge time constraint. There are three aspects to this, the first is the amount of work and the number of things to be done, secondly the subjective time and experience aspects of the employee assumed if the increased workload rate also increases, and thirdly the mental and physical effort employed by employees reflects an employee's response to his duties (Permana, 2017). 


\section{Concept of workload:}

Mondy (2011) states that there are two types of workload, essentially: (1) quantitative work load; (2) qualitative work load. Huey and Wickens in Gibson et al. (2007) mention the impact of workload on workers that can be abstracted as follows: (1) increased work difficulties sometimes lead to down performance; (2) the response time and error increases for different tasks; (3) increased errors for tasks that must be completed within a certain time interval (tracking task); (4) the work load imposed by a single task may interfere with the performance of other activities carried out jointly; (5) prolonged periods of extended workload may cause work fatigue.

Gibson et al. (2007) mention the benefits of a division of labor as follows: (1) get technical benefits; (2) economic benefits; (3) there is a specialization of work.

\section{Factors affecting workload:}

Factors affecting the workload in Aminah Soleman's research (Arika Journal, 2011) are as follows:

1. External factors: Expenses that come from outside the worker's body, such as: (a) Tasks, these include physical tasks such as, work station, workplace layout, workspace conditions, working environment conditions, work attitude, mode of transport, loads raised. While mental tasks include, responsibility, work complexity, worker emotions and so on; (b) Working organization that includes length of working time, rest time, work shift, work system and so on; (c) Work environment that can provide additional burden which includes, physical work environment, chemical work environment, biological work environment and psychological work environment.

2. Internal factors: Internal factors are factors derived from the body as a result of external workload reactions that have potential stressors, including somatic factors (sex, age, body size, nutritional status, health condition, etc.), and psychological factors (motivation, perception, trust, desire, satisfaction, etc.).

3. Compensation: According to Simamora (2007), compensation is what employees receive in exchange for their contribution to the organization. From this definition it can be concluded that the compensation is all forms of payment provided by the company to employees as a reward for the implementation of duties or contributions to the company. The amount of remuneration or compensation has been determined and known beforehand, so that employees will surely know the amount of remuneration or compensation that will be received. This compensation will be used by employees and their families to meet their needs. The amount of compensation reflects the status, recognition, and level of fulfillment that will be accepted by employees. The higher the compensation received by the employee, the higher the position, the better the status, and the fulfillment of the needs are enjoyed more and more as well. Thus, the satisfaction of work is also getting better, herein lies the 
importance of compensation for employees as a seller of energy (physical and mind).

4. Concept of compensation: Noe (2013: 374) divides the compensation into two parts: direct financial compensation consisting of salary, wages, and incentives (commissions and bonuses), and indirect financial compensation in the form of various facilities and benefits:

a) Direct compensation. Direct compensation is an award received by employees in the form of money. Direct compensation may be: (a) salary as a compensation paid periodically to permanent employees and has a certain guarantee; (b) wages are compensation paid to a daily employee based on a mutual agreement: (c) incentives are compensation given to employees to achieve targets; (d) bonus is a specific given to employees intended to improve employee work productivity.

b) Indirect compensation. Indirect compensation is a compensation not directly felt by the employee, i.e., benefits and services. This compensation is an additional compensation provided both financially and non-financially under the company's policies to all employees. Indirect compensation: (i) payment of wages for time not at work: (ii) economic protection against hazards, including: old-age benefits, medical benefits, retirement plans; (iii) employee service programs, including: recreation, cafeteria, housing, educational scholarships, and other facilities.

5. Work Discipline: Sjafri and Aida (2007) suggest that the discipline of work is the nature of employees who consciously obey the norms and regulations of certain organizations in work. Being disciplined is the awareness of a person obeying all corporate rules and prevailing social norms. Consciousness is the attitude of a person who voluntarily obeys all rules and is aware of his duties and responsibilities. Willingness is the attitude, behavior and actions of a person in accordance with company regulations both written and unwritten. Based on the opinions above, it can be concluded that the discipline of work is the attitude and behavior of employees / employees who are able to obey and obey the rules that apply, both written and unwritten and able to implement them.

6. The concept of work discipline: Work discipline is divided into three, namely: 1) preventive discipline which consists of activities undertaken to encourage employees to follow various standards and rules, so that fraud can be prevented; 2) corrective discipline which consists of activities undertaken to deal with violations of rules that try to avoid further violations of norms. Corrective activity is often a form of punishment and is called disciplinary action; 3) progressive discipline which consists of activities to give heavier penalties for repeated violations. The purpose of this progressive discipline is for employees to take corrective actions before getting a more serious punishment.

7. Indicators of work discipline: According to Sinungan (2007) the indicators of the work discipline are as follows: 
1) Attendance which is the data collection of employee attendance which is also a tool to see the extent to which the employees comply with regulations that apply within the company.

2) Attitudes and behavior which is the level of self-adjustment of a person in carrying out all the duties of his superiors including implementing company regulations both written and unwritten.

3) Responsibility is the result of taking ownership by an employee on the tasks assigned to him.

8. Work productivity: There are several opinions about the definition of productivity. Based on research by Nawawi and Martini (2007) employee productivity is the ability of personnel or employees to produce something in the work, which can be seen and compared between the work of individuals in the form of money with the cost incurred for the individual in order to produce something. Sedarmayanti (2010) states that work productivity is how to produce or improve the goods and services as much as possible by utilizing resources efficiently. Therefore, productivity is often defined as the ratio between output and input between units of time. Mathis et al. (2011), define work productivity as a comparison between the totality of expenditure at a given time divided by the totality of inputs during the period.

9. The Concept of productivity: The concept of productivity can basically be seen from two dimensions, namely of individuals and organizational. Assessment of productivity problems from the dimensions of the individual is none other than to see productivity especially in relation to the characteristics of individual personality traits. In this context, the essence of understanding productivity is a mental attitude that always has the view that the quality of life today must be better than yesterday, and tomorrow must be better than today (Kusnendi, 2003). Sinungan (2007) also proposes two sets of conditions for high individual productivity:

1) First group: a) level of education and expertise; b) type of technology and production; c) working conditions; d) health, physical and mental capability.

2) Second group: a) mental attitudes (on duty), peers and supervisors; b) diversity of duties; c) incentive systems (wages and bonus systems); d) job satisfaction.

The concept of productivity as a whole is another dimension of the effort to achieve the quality and quantity of an activity process with regards to the subject of economics. Therefore, one is always oriented to how to think and act to utilize the input source to get the optimum output. Thus, the concept of productivity in this view is always placed on the framework of technical relations between inputs and outputs (Kusnendi, 2007). It can be concluded that work productivity is the ability to produce goods and services from various resources or production factors used to improve the quality and quantity of work produced within a company.

\section{Methods}


This research is done quantitatively with a descriptive associative method. The population of this research is employees of PT., Tokio Marine, as many as 259 employees. The study population was used as the source of the sample, and the sample obtained amounted to 120 respondents. Data were obtained by distributing questionnaires to employees of PT., Tokio Marine Life Insurance Indonesia. With the questionnaire, the researcher asked respondents to fill the question independent of the researchers contained in the list of questions given to the respondents. An alternative way to get the necessary data sources is by field surveys / delivering questionnaires directly via email or via phone.

\section{Results and discussion}

Descriptive statistical analysis was used to describe data of this study, where the variables are Job Stress variables, Workload, Compensation, and Work Discipline of Work Productivity. Here are the results of data analysis using descriptive statistics, namely as follows:

Table 1. Descriptive Statistics Results

\begin{tabular}{llllll}
\hline & N & Minimum & Maximum & Mean & Std. Deviation \\
\hline Prod_krj & 120 & 9.00 & 20.00 & 16,4500 & 2,27093 \\
Stress_krj & 120 & 12.00 & 25.00 & 20,3500 & 3,12660 \\
Beban_krj & 120 & 10.00 & 20.00 & 16,3667 & 2,43895 \\
Kompensasi & 120 & 10.00 & 20.00 & 16,4917 & 2,34430 \\
Dis_krj & 120 & 8.00 & 20.00 & 16,3167 & 2,70693 \\
Valid N (listwise) & 120 & & & & \\
\hline
\end{tabular}

Source: Primary data processed, 2018.

From the Table above, one can notice that the number of samples (N) is 120 respondents. The variable Prod_krj has a mean of 16.4500. The minimum value of the Prod_krj variable is of 9.00 and the maximum value is 20.00 , with a standard deviation of 2.27093. The Stress_krj variable shows a minimum value of 12.00 and a maximum value of 25.00 with a mean value of 20.3500 . The standard deviation of Stress_krj is 3.12660, where Standard deviation shows the variance.

The variable Burden_krj has a minimum value of 10.00 and a maximum value of 20.00 with a mean of 16.3667 and Standard deviation of 2.43895, where Standard deviation shows the variance. In the Compensation variable, it shows the minimum value of 10.00 and the maximum value of 20.00 and the mean value of 16.4917 with the value of Standard deviation of 2.34430, where Standard deviation shows the variance. In the Discipline_krj variable, the minimum value is 8.00 and the maximum value of 20.00 is the mean value of 16.3167 and the standard deviation of 2.70693 where the Standard deviation shows the variance. 


\subsection{Classic assumption tests}

\section{Normality Test:}

The normality test aims to test whether in the regression model, the intruder or residual variable has a normal distribution. If there is normality, then the residual variable will be normally distributed and independent. To detect the normality of the model the Kolmogrov-Smirnov non-parametical statistical test is performed. Normality test results are presented in Table 2 as follows:

Table 2. Normality Test

One-Sample Kolmogorov-Smirnov Test

\begin{tabular}{|c|c|c|}
\hline & & $\begin{array}{l}\text { Unstandardized } \\
\text { Residual }\end{array}$ \\
\hline $\mathrm{N}$ & & 120 \\
\hline \multirow{3}{*}{ Normal Parameters ${ }^{\mathrm{a}, \mathrm{b}}$} & Mean & $0 \mathrm{E}-7$ \\
\hline & Std. Deviation & ,98853217 \\
\hline & Absolute & ,044 \\
\hline \multirow[t]{2}{*}{ Most Extreme Differences } & Positive & 041 \\
\hline & Negative &,- 044 \\
\hline Kolmogorov-Smirnov Z & &, 481 \\
\hline Asymp. Sig. (2-tailed) & & 975 \\
\hline
\end{tabular}

a. Test distribution is Normal.

b. Calculated from data.

Based on the SPSS output display, the regression result has a Kolmogorov-Smirnov value of 0.975 and is significant at 0.05 . This indicates that the residual data in the regression is normally distributed.

\section{Multicollinearity test:}

Multicollinearity test aims to test whether the regression model found the correlation between independent variables. A good regression model should not be correlated among independent variables. Multicollinearity can be seen from Tolerance and Variance Inflation Factor (VIF) values. Based on Table 3 from the coefficients on the regression output one can see that the tolerance for each variable is as follows:

Table 3. Multicolinearity test

Coefficients $^{\mathrm{a}}$

\begin{tabular}{|c|c|c|c|c|c|c|c|}
\hline \multirow[t]{2}{*}{ Model } & \multicolumn{2}{|c|}{$\begin{array}{l}\text { Unstandardized } \\
\text { Coefficients }\end{array}$} & \multirow{2}{*}{$\begin{array}{l}\text { Standardized } \\
\text { Coefficients } \\
\text { Beta }\end{array}$} & \multirow[t]{2}{*}{$\mathrm{t}$} & \multirow[t]{2}{*}{ Sig. } & \multicolumn{2}{|c|}{$\begin{array}{l}\text { Collinearity } \\
\text { Statistics }\end{array}$} \\
\hline & $\mathrm{B}$ & Std. Error & & & & Tolerance & VIF \\
\hline (Constant) & 1,411 & ,875 & & 1,613 & ,109 & & \\
\hline Stress_krj &, 145 & ,208 & , 199 - & ,696 & ,488 & ,020 & 9,768 \\
\hline 1 Beban_krj &,- 092 & ,263 &,- 099 &,- 351 & ,726 & ,021 & 8,418 \\
\hline Kompensasi & ,821 & ,046 & ,848 & 17,856 & ,000 & ,031 & 1,369 \\
\hline Dis_krj & ,003 & ,036 & ,004 & ,097 - r & ,923 & ,013 & 1,095 \\
\hline
\end{tabular}

a. Dependent Variable: Prod_krj 
The output SPSS view shows that the tolerance values of all variables are close to number 1. Thus, it can be concluded that the regression detection does not occur multicollinearity problem.

\section{Heteroscedasticity test:}

The heteroscedasticity test aims to test whether in the regression model there is a variance inequality of the residual between one observation to the other. If the variance of the residual of one observation to another observation remains, then it is called homoscedasticity and if different is called heteroscedasticity. In this study to detect the presence or absence of heteroscedasticities, one can conduct the Park test (Table 4).

Table 4. Heteroscedasticity Test Coefficients $^{\text {a }}$

\begin{tabular}{|c|c|c|c|c|c|c|c|}
\hline \multirow[t]{2}{*}{ Model } & \multicolumn{2}{|c|}{$\begin{array}{l}\text { Unstandardized } \\
\text { Coefficients }\end{array}$} & \multirow{2}{*}{$\begin{array}{l}\text { Standardized } \\
\text { Coefficients } \\
\text { Beta } \\
\end{array}$} & \multirow[t]{2}{*}{$\mathrm{t}$} & \multirow[t]{2}{*}{ Sig. } & \multicolumn{2}{|c|}{$\begin{array}{l}\text { Collinearity } \\
\text { Statistics }\end{array}$} \\
\hline & B & Std. Error & & & & Tolerance & VIF \\
\hline (Constant) & $-3,766$ & 1,719 & & $-2,191$ & .030 & & \\
\hline Stress_krj &, 031 & ,409 & ,049 & 077 & ,939 & ,020 & 9,768 \\
\hline 1 Beban_krj & 063 & ,517 & 077 & 122 & 903 & 021 & 8,418 \\
\hline Kompensasi &,- 086 & ,090 &,- 101 &,- 952 & ,343 & 031 & 1,369 \\
\hline Dis krj &, 148 & 070 & 201 & 2,114 & 237 & 013 & 1,095 \\
\hline
\end{tabular}

a. Dependent Variable: Inres1kuadrat

Based on the SPSS output display above, the result of heteroskedasticities using Park test resulted that the significance of all the variables is greater than the confidence level of 10 percent $(0.1)$. So, it can be concluded that the regression model does not have heteroskedasticities.

\section{Multiple Linear Regression Analysis:}

$\mathrm{F}$ test is used to test the independent variables and together with other variables, to see whether the independent variable influences the dependent variable significantly (Table 5).

Table 5. Test F

ANOVA $^{\mathrm{a}}$

\begin{tabular}{|c|c|c|c|c|c|c|}
\hline \multicolumn{2}{|c|}{ Model } & Sum of Squares & df & Mean Square & $\mathrm{F}$ & Sig. \\
\hline \multirow{3}{*}{1} & Regression & 497,414 & 4 & 124,353 & 122,978 &, $000^{\mathrm{b}}$ \\
\hline & Residual & 116,286 & 115 & 1,011 & & \\
\hline & Total & 613,700 & 119 & & & \\
\hline
\end{tabular}

a. Dependent Variable: Prod_krj

b. Predictors: (Constant), Dis_krj, Stress_krj, Kompensasi, Beban_krj

Source: Primary data processed, 2018. 
From the ANOVA or F test, the calculated $\mathrm{F}$ value is 122,978 with probability 0.000 . Because the probability is less than 0.05 , the regression model can be used to predict work productivity, or it can be said that job stress, workload, compensation, and work discipline together affect work productivity.

$\mathrm{T}$ test is used to determine the influence of each independent variable to the dependent variable. If the value of sig. $<0.05$ and $t$ value > table, then $\mathrm{Ho}$ is rejected, meaning there is an influence of the free variable on the dependent variable (Table 6).

Table 6. Test T

\begin{tabular}{|c|c|c|c|c|c|c|}
\hline \multirow{2}{*}{\multicolumn{2}{|c|}{ Model }} & \multicolumn{2}{|c|}{$\begin{array}{l}\text { Unstandardized } \\
\text { Coefficients }\end{array}$} & \multirow{2}{*}{$\begin{array}{l}\text { Standardized } \\
\text { Coefficients } \\
\text { Beta }\end{array}$} & \multirow[t]{2}{*}{$\mathrm{t}$} & \multirow[t]{2}{*}{ Sig. } \\
\hline & & $\mathrm{B}$ & Std. Error & & & \\
\hline \multirow{5}{*}{1} & (Constant) & 1,411 &, 875 & & 1,613 & , 109 \\
\hline & Stress_krj & ,145 & ,208 & , 199 & ,696 & 488 \\
\hline & Beban_krj &,- 092 & ,263 &,- 099 &,- 351 & ,726 \\
\hline & Kompensasi &, 821 & ,046 & ,848 & 17,856 & ,000 \\
\hline & Dis_krj & ,003 &, 036 & ,004 & ,097 & ,923 \\
\hline
\end{tabular}

a. The job stress variable has no effect on productivity. This is evidenced by a statistical value of 0.488 that is $>0.05$. Thus, it is not in accordance with the initial hypothesis (H1) which states that work stress has a significant effect on productivity (H1 rejected).

b. Workload has no effect on productivity. This is evidenced by a statistical value of 0.726 that is $>0.05$. Thus, this is not in accordance with the initial hypothesis $(\mathrm{H} 2)$ which states that there is a significant effect on productivity (H2 rejected).

c. Compensation affects productivity. This is evidenced by a statistical value of 0.000 that is $<0.05$. This is consistent with the initial hypothesis (H3) which states that compensation affects productivity (H3 accepted).

d. Work discipline has no effect on productivity. This is evidenced by a statistical value of 0.923 which is $>0.05$. Thus, in accordance with the initial hypothesis (H4) which states that the work discipline affects productivity (H4 rejected).

\section{Coefficient of Determination test:}

Testing the coefficient of determination ( $\mathrm{R}$ square) is done to know the contribution which independent variables have on the dependent variable (Table 7).

Table 7. Model Summary ${ }^{b}$

\begin{tabular}{llllll}
\hline Model & $\mathrm{R}$ & R Square & $\begin{array}{l}\text { Adjusted } \\
\text { Square }\end{array}$ & $\begin{array}{l}\text { R } \\
\text { Std. Error of the Durbin-Watson } \\
\text { Estimate }\end{array}$ & \\
\hline 1 &, $900^{\mathrm{a}}$ &, 811 &, 804 & 1,00558 & 1,574 \\
\hline
\end{tabular}

a. Predictors: (Constant), Dis_krj, Stress_krj, Kompensasi, Beban_krj

b. Dependent Variable: Prod_krj 
From the output display of SPSS model summary, the magnitude of $\mathrm{R}$ square is 0,811 , which means $81,1 \%$ of work productivity variation can be explained by the variation of the four independent variables - work stress, work load, compensation, and work discipline. While the remainder $18.9 \%$ is explained by other causes outside the model.

\section{Discussion:}

1. Work stress does not affect productivity:

The job stress variable has no effect on productivity. This is evidenced by a statistical value of 0.488 that is $>0.05$. Thus, it is not in accordance with the initial hypothesis (H1) which states work stress has a significant effect on productivity. Hariyono et al. (2009) suggest that stress is a condition of tension that affects the emotions, thinking processes, and conditions of a person. Job stress is a process that can affect the psychological condition and disrupt a person in his job. But when a person has good emotional intelligence, the individual is able to manage his emotions well.

\section{Workload has no effect on productivity:}

Workload has no effect on productivity. This is evidenced by a statistical value of 0.726 that is $>0.05$. Thus, it is not in accordance with the initial hypothesis $(\mathrm{H} 2)$ which states that there is a significant effect on productivity. Mondy (2011) states that "workload is the tasks assigned labor or employees to be completed at any given time using the skills and potential of the workforce". In this case, the company has provided workload in accordance with the potential workforce. The Company has also been measuring according to applicable work standards.

\section{Compensation affects productivity:}

This is evidenced by a statistical value of 0.000 that is $<0.05$. This is consistent with the initial hypothesis $(\mathrm{H} 3)$ which states that compensation affects productivity. Noe (2013) divides the compensation into two parts: direct financial compensation consisting of salary, wages, and incentives (commissions and bonuses), and indirect financial compensation in the form of various facilities and allowances. Apparently, compensation has a very important motivating factor in supporting employee productivity. Employees and firms recognize mutual relationships in the workplace and use compensation to increase morale so that productivity can increase. Generally, companies tend to use variable compensation in the form of incentives to stimulate employee productivity. So, the better the compensation given the employee, the higher the productivity of the employee.

4. Work discipline has no effect on productivity:

This is evidenced by a statistical value of 0.923 which is $>0.05$. Thus, in accordance with the initial hypothesis (H4) which states that the work discipline has an effect on productivity, the hypothesis is rejected. 
Sjafri and Aida (2007) suggest that the discipline of work is the nature of employees who consciously obey certain organizational norms and regulations in work. Being disciplined is the awareness of a person obeying all corporate rules and prevailing social norms. Working discipline does not affect the productivity of work because employees still hold the standards and norms in the organization.

5. Work stress, workload, compensation and work discipline affect the productivity together:

Job stress, workload, compensation and work discipline affect productivity together. From the ANOVA or F test, the calculated F value is 122,978 with probability 0.000 . Because the probability is smaller than 0.05 , the regression model can be used to predict work productivity, or it can be said that job stress, workload, compensation, and work discipline together affect work productivity. This is in accordance with the initial hypothesis (H5) which states that job stress, workload, compensation and work discipline affect productivity.

\section{Conclusion}

Based on the results of this research, the effect of Work Stress, Working Expense Compensation and Work Discipline on Work Productivity together equal to $81.1 \%$. The Job stress variable has no effect on productivity. This is evidenced by a statistical value of 0.488 that is $>0.05$. Thus, it is not in accordance with the initial hypothesis (H1) which states Work stress has a significant effect on Productivity.

Workload has no effect on Productivity. This is evidenced by a statistical value of 0.726 that is $>0.05$. Thus, it is not in accordance with the initial hypothesis $(\mathrm{H} 2)$ which states that there is a significant effect on Productivity.

Compensation affects Productivity. This is evidenced by a statistical value of 0.000 that is $<0.05$. This is consistent with the initial hypothesis (H3) which states that Compensation affects Productivity.

Work Discipline has no effect on Productivity. This is evidenced by a statistical value of 0.923 which is $>0.05$. Thus, this is in accordance with the initial hypothesis (H4) which states that the Work Discipline effect on Productivity.

Job stress, workload, compensation and work discipline affect Productivity together. From the ANOVA or F test, the calculated F value is 122,978 with probability 0.000 . Because the probability is smaller than 0.05 , the regression model can be used to predict work productivity, or it can be said that job stress, workload, compensation, and work discipline together affect work productivity. This is in accordance with the initial hypothesis (H5) which states that job stress, workload, compensation and work discipline affect productivity. 
Together these four variables affect work productivity. The higher the work stress, which is offset by an increase in workload but not offset by compensation adjustments, while employees are non-compliant with the rules, this will decrease work productivity.

\section{References:}

Afia, I.N., Ranu, M.E. 2013. Contribution of Workload, Work Discipline, Relationships with Workers' Friends of Work Productivity at PT Viccon Modern Industry. Office Administration Journal (JPAP), 1(3).

Bernanthos, B. 2018. Employees' Performance in Islamic Banking. European Research Studies Journal, 21(1), 31-42.

Davidson, B. 2011. How to Measure Human Resources Management? Jakarta, Kencana Prenada Media Group.

Gibson, B.R., Lawrence, S.J., Leclaire, J.P., Powell, C.D., Smart, K.A. 2016. Yeast responses to stresses associated with industrial brewery handling. FEMS Microbiol Rev, 31(5), 535-569.

Nawawi, H., Martini, M. 2007. Applied Research. Yogyakarta, Gajah, Mada University Press.

Hariyono, W., Suryani, D., Wulandari, Y. 2009. Relationship between Workload, Job Stress and Conflict Level with Exhaustion of Nurse Work at Yogyakarta Islamic Hospital PDHI Yogyakarta City, Fak. Public Health, Ahmad Dahlan University, Yogyakarta, KES MAS, 3(03), 186-197.

Kusnendi, K. 2003. Economics of Human and Nature Resources. Jakarta. Universitas Terbuka.

Mathis, L., Robert, H., Jackson, J. 2011. Human Resource Management (ed. 10). Jakarta, Salemba Empat.

Mangkunegara, Anwar Prabu. 2013. Human resource management company, Bandung, Teenager Rosdakarya.

Noe, R.A. 2013. Human Resource Management. Issue 6, Books 1 \& 2, Jakarta, Salemba Empat.

Permana, D. 2017. Toward the Best Model of Strategy Implementation in Indonesian Islamic Banking from the Lens of Strategic Clarity. European Research Studies Journal, 20(4B), 3-15.

Sedarmayanti, M. 2010. Human Resources and Work Productivity. Bandung, CV., Mandar Advanced.

Simamora, H. 2007. Human Resource Management. STIE YKPN, Yogyakarta.

Sinungan, M. 2007. What and How Productivity bit BumiAksara, Jakarta.

Sjafri Mangkuprawira, T.B. Aida Vitayala Hubeis. 2007. Manajemen Mutu Sumber Daya Manusia. Ghalia Indonesia, Bogor.

Wicaksono, D.A. 2015. Employee Work Productivity Improvement Through Leadership, Work Discipline Motivation and Compensation at PT, Danatrans Service Logistics Semarang. 